\title{
Article/Artigo
}

\section{Biological, behavioral, and socioeconomic factors associated with death from AIDS in Brasília, Brazil, in 2007}

\author{
Fatores biológicos, comportamentais e socioeconômicos associados ao óbito por Aids em \\ Brasília, Brasil, em 2007
}

\section{Luiz Antonio Bueno Lopes ${ }^{1,2}$ and Edina Mariko Koga da Silva ${ }^{3}$}

\begin{abstract}
Introduction: In the jurisdiction of Brasília, Brazil, significant reductions in mortality rates and lethality resulting from acquired immunodeficiency syndrome (AIDS) were observed shortly after the introduction of highly active antiretroviral therapy. In recent years, however, the decline of these rates has not been as significant. Non-adherence to treatment and delayed diagnosis appear to be the main factors that increase the risk of death from AIDS. Behavioral, socioeconomic, and biological factors could also be associated with increased risk of death due to AIDS. This study aimed to identify which of these factors were associated with deaths from AIDS in Brasília. Methods: A case-control study was undertaken using the data recorded in the Information System of Notifiable Diseases. Cases consisted of AIDS deaths occurring in 2007, residing in Brasília, and over 12 years of age. Controls consisted of AIDS patients who did not die until December 31 2007, also residing in Brasília, and over 12 years of age. For each group, frequency and proportion tables for the variables were prepared. The statistical association of each factor in isolation with the occurrence of the deaths was verified through a model of multivariate analysis using logistic regression. Results: The factors that were associated with an increased risk of death were intravenous drug use, age 50 years or more, and residing in a region whose residents have low per capita income. Conclusions: We identified factors associated with death due to AIDS that can guide health planning.
\end{abstract}

Keywords: Mortality. Lethality. Drug users. Age distribution. Socioeconomic factors.

\section{RESUMO}

Introdução: No Distrito Federal, Brasil, houve importante redução das taxas de mortalidade e de letalidade por AIDS logo após a introdução da terapia antirretroviral altamente ativa, mas nos últimos anos o declínio dessas taxas não foi significativo. Não adesão ao tratamento e diagnóstico tardio parecem ser os principais fatores que elevam o risco de óbito por AIDS. Fatores comportamentais, socioeconômicos e biológicos também podem estar associados ao maior risco de óbito por AIDS. O objetivo deste estudo foi identificar quais desses fatores apresentaram associação com os óbitos por AIDS no Distrito Federal. Métodos: Estudo do tipo caso-controle, utilizando os dados registrados no Sistema de Informação de Agravos de Notificação, em que foram considerados casos os óbitos por AIDS ocorridos em 2007, residentes no Distrito Federal e maiores de 12 anos de idade e, controles os doentes de AIDS que não foram a óbito até 31 de dezembro de 2007, também residentes no Distrito Federal e com mais de 12 anos de idade. Prepararam-se, para cada grupo, tabelas de frequência e proporção para as variáveis. Foi verificada a associação estatística de cada fator isoladamente com a ocorrência dos óbitos e também por meio de um modelo de análise multivariável por regressão logística. Resultados: Os fatores que apresentaram associação com maior risco de óbito foram: usar drogas injetáveis, ter idade maior ou igual a 50 anos e residir em local cujos moradores possuem baixa renda per capita. Conclusões: Identificaram-se fatores associados ao óbito por AIDS que poderão nortear o planejamento em saúde.

Palavras-chaves: Mortalidade. Letalidade. Usuários de drogas. Distribuição por idade. Fatores socioeconômicos.

1. Diretoria de Vigilância Epidemiológica, Secretaria de Estado de Saúde do Distrito Federal, Brasília, DF. 2. Câmara Legislativa do Distrito Federal, Brasília, DF. 3. Programa de Pós-Graduação em Medicina Interna e Terapêutica, Departamento de Medicina, Universidade Federal de São Paulo, São Paulo, SP. Address to: Dr. Luiz Antonio Bueno Lopes. Diretoria de Vigilância Epidemiológica/SES-DF. SGAN Q. 601, Lotes O e P, sala 9, 70830-010 Brasília, DF, Brasil.

Phone: 5561 3323-4517.

e-mail: lablopes@gmail.com

Received in 29/03/2011

Accepted in 24/01/2012

\section{INTRODUCTION}

The acquired immunodeficiency syndrome (AIDS) pandemic is an important public health problem. According to estimates by the World Health Organization in 2008, there were 33.4 million people in the world infected with human immunodeficiency virus (HIV) ${ }^{1}$.

In 1996 a highly active antiretroviral therapy was developed. This new therapy provided patients with great improvements in the quality of life and a significant increase in life expectancy ${ }^{2}$. Not all countries, however, have succeeded in reducing the number of AIDS deaths, mainly because of the high cost of these drugs. In 2008 the number of deaths from the disease worldwide was estimated at two million ${ }^{1}$.

In Brazil a vast logistical structure was set up under the coordination of the Ministry of Health, involving the state and municipal health departments, to provide the necessary medication, the appropriate examinations to monitor the evolution of patients, the training for health professionals, and the information systems to control the execution of examinations and the distribution of medication. In addition, clinical guidelines for treatment have been established, which are followed throughout the country. In 2006 there were 180,000 people in the country using antiretrovirals, with the expenses on these medications standing at US\$400 million ${ }^{3}$.

Several authors indicate that today the majority of AIDS deaths are related to the non-adherence to treatment and delayed diagnosis, and that some biological, behavioral, and socioeconomic factors, such as gender, age, income, education level, and HIV exposure category, can influence the first two conditions and thus may be associated with such deaths ${ }^{4-7}$.

The implementation of Law N 9313/96, which provides AIDS patients free access to drugs for AIDS treatment, associated with the advent of highly effective antiretroviral therapy, has led to a rapid reduction of mortality rates from AIDS. Since 2004, however, the pace of this decline has become much slower in the Federal District (the jurisdiction of Brasília, the capital of Brazil) and the rest of the country ${ }^{8-10}$. 
AIDS treatment technology has limitations. HIV resistance to the antiretroviral drugs is one of the factors that may cause the failure of the therapy. However, the development of new medicines by the pharmaceutical industry has been very fast, and in 2009, seventeen antiretroviral drugs were available in the Brazilian Public Health Service $^{11}$, ensuring a high list of treatment options and reducing the possibility of treatment failure. One would therefore expect that mortality rates would continue to fall at an accelerated pace. Since this is no longer occurring, however, the need to better understand the factors associated with deaths from AIDS becomes more relevant because it will allow the establishment of a profile of the patient at increased risk of death and the implementation of public policies that devote more and better-directed efforts to prevent this outcome.

The aim of this study was to identify the biological, behavioral, and socioeconomic factors associated with AIDS deaths among residents of the Federal District in Brazil, as recorded in the official information systems.

\section{METHODS}

A case-control study was conducted, using secondary data obtained from the records of the Information System of Notifiable Diseases (SINAN), after updating them by cross-referencing them with the records of the Mortality Information System (SIM).

To obtain data that would allow the investigation of the link between certain conditions and death from AIDS, the use of the official information systems is possible. The main information system, which includes data from patients diagnosed both in the public and the private health services, since AIDS is a reportable disease, is SINAN. Information on cases registered in this system is obtained through an epidemiological investigation form, filled out by a health professional, for each reported case. In the SIM are registered all deaths that occurred in the country, with their cause.

The study included patients registered in the SINAN database of the State Health Department of the Federal District, taken on June 19,2009, who were registered in accordance with the criteria for case definition for AIDS from the Health Department ${ }^{12}$. These patients were residents of the Federal District, over 12 years of age, diagnosed before 2007, and had no record of death until December 31, 2006.

Two groups were considered according to the established selection criteria: I) those who passed away from aids in 2007 (cases), and II) those who were alive on December 31, 2007 (controls).

We chose the year 2007 for analysis because it was the most recent year for which information was complete. The control group was not matched.

For each group, frequency and proportion tables were prepared for the following variables: gender, education, race, exposure category, place of residence based on per capita income, and age.

A statistical analysis was performed for each variable. We calculated the value of chi-square test, as the degrees of freedom of the variable factors, and the $\mathrm{P}$ value.

Next, a model of multivariate logistic regression analysis was drafted, including the factors that in bivariate analysis showed $\mathrm{p}<0.25$. For this analysis was chosen to transform the independent variables into binary variables, assuming the presence or absence of possible factor associated with the outcome observed in the unadjusted analysis.

\section{RESULTS}

The group of cases (deaths) comprised 102 records and the controls (alive) 3,302 records. Table 1 shows the distribution of records according to variable, factor, and study group.

TABLE 1 - Distribution of records according to variable, factor, and study group, Brasília, Brazil, 2007.

\begin{tabular}{|c|c|c|c|c|}
\hline \multirow[b]{3}{*}{ Variable/factor } & \multicolumn{4}{|c|}{ Study group } \\
\hline & \multicolumn{2}{|c|}{$\begin{array}{c}\text { Case } \\
\text { (AIDS deaths) }\end{array}$} & \multicolumn{2}{|c|}{$\begin{array}{c}\text { Control } \\
\text { (living with AIDS) }\end{array}$} \\
\hline & $\mathbf{n}$ & $\%$ & $\mathbf{n}$ & $\%$ \\
\hline \multicolumn{5}{|l|}{ Gender } \\
\hline male & 74 & 72.5 & 2,298 & 69.6 \\
\hline female & 28 & 27.5 & 1,004 & 30.4 \\
\hline \multicolumn{5}{|l|}{ Race } \\
\hline white & 32 & 31.4 & 652 & 19.7 \\
\hline black & 10 & 9.8 & 136 & 4.1 \\
\hline asian & - & - & 18 & 0.5 \\
\hline mulatto & 33 & 32.4 & 687 & 20.8 \\
\hline indigenous & 1 & 1.0 & 9 & 0.3 \\
\hline ignored/not filled out & 26 & 25.5 & 1,800 & 54.5 \\
\hline \multicolumn{5}{|c|}{ Education (years of schooling) } \\
\hline illiterate & 1 & 1.0 & 63 & 1.9 \\
\hline 1 to 3 & 15 & 14.7 & 300 & 9.1 \\
\hline 4 to 7 & 24 & 23.5 & 756 & 22.9 \\
\hline 8 to 11 & 23 & 22.5 & 935 & 28.3 \\
\hline 12 and more & 13 & 12.7 & 536 & 16.2 \\
\hline ignored/not filled out & 26 & 25.5 & 712 & 21.6 \\
\hline \multicolumn{5}{|l|}{ Exposure category } \\
\hline MSM & 25 & 24.5 & 1,077 & 32.6 \\
\hline heterosexual & 29 & 28.4 & 1,517 & 45.9 \\
\hline IDU & 15 & 14.7 & 370 & 11.2 \\
\hline hemophiliac & - & - & 6 & 0.2 \\
\hline blood transfusion & - & - & 8 & 0.2 \\
\hline vertical & - & - & 1 & 0.0 \\
\hline ignored & 33 & 32.4 & 323 & 9.8 \\
\hline \multicolumn{5}{|c|}{ Residence according to income } \\
\hline $\mathrm{R} \$ 1,000.00$ or more & 19 & 18.6 & 637 & 19.3 \\
\hline $\mathrm{R} \$ 500.00$ to $\mathrm{R} \$ 999.00$ & 21 & 20.6 & 1,113 & 33.7 \\
\hline up to $\mathrm{R} \$ 499.00$ & 58 & 56.9 & 1,413 & 42.8 \\
\hline ignored/not filled out & 4 & 3.9 & 139 & 4.2 \\
\hline \multicolumn{5}{|l|}{ Age group (years) } \\
\hline 13 and 14 & - & - & - & - \\
\hline 15 to 19 & 1 & 1.0 & 8 & 0.2 \\
\hline 20 to 29 & 8 & 7.8 & 289 & 8.8 \\
\hline 30 to 39 & 30 & 29.4 & 1,181 & 35.8 \\
\hline 40 to 49 & 39 & 38.2 & 1,251 & 37.9 \\
\hline 50 to 59 & 19 & 18.6 & 424 & 12.8 \\
\hline 60 to 69 & 2 & 2.0 & 119 & 3.6 \\
\hline 70 to 79 & 2 & 2.0 & 26 & 0.8 \\
\hline 80 or more & - & - & 4 & 0.1 \\
\hline ignored/not filled out & 1 & 1.0 & - & - \\
\hline Total & 102 & 100.0 & 3,302 & 100.0 \\
\hline
\end{tabular}

Source of data: Information System of Notifiable Diseases. AIDS: acquired immunodeficiency syndrome MSM: men who have sex with men; IDU: injecting drug users. 
In the group of cases (deaths), the average time between the date of AIDS diagnosis and death was 1,104 days ( $S D=1,585$ days). In the control group (alive), the average time between the date of AIDS diagnosis and the last day of the year 2007 was 2,271 days ( $\mathrm{SD}=1,533$ days).

In the independent analysis of each factor to determine the statistical correlation between the presence of the factor and the frequency of deaths, an association emerged between the elevated risk of death and residence in places with low income . A statistical analysis of race was not performed because of the large number of records without this information or with the field left blank. Table 2 shows the results of the not adjusted analysis.
In the multivariate logistic regression analysis model, those categories that showed a possible association with increased risk of death were included, characterized by $\mathrm{p}<0.25$, in the not adjusted analysis. The variables were classified as follows on: exposure category (drug users or not), income (less than or greater than R \$ 499.00), age (less than or greater than 50 years) and education (less than or greater than 8 years). The factors that were associated with risk of death after multivariate analysis were exposure category of IDU $(\mathrm{OR}=2.13,95 \% \mathrm{CI}=1.16-3.91, \mathrm{p}=0.01)$, age above 50 years $(\mathrm{OR}=1.82,95 \% \mathrm{CI}=1.02-3.24, \mathrm{p}=0.04)$, and residence in places with incomes of up to $\mathrm{R} \$ 499.00(\mathrm{OR}=1.65,95 \% \mathrm{CI}=1.01-2.71$, $\mathrm{p}=0.04)$. Table 3 presents the results of the multivariate analysis.

TABLE 2 - Results of the independent analysis according to evaluated risk factors for death from AIDS, Brasilia, Brazil, 2007

\begin{tabular}{|c|c|c|c|}
\hline Variable/factor & Cases (n) & Control (n) & $\begin{array}{l}\text { Results of statistical } \\
\text { analysis of the category }\end{array}$ \\
\hline Gender & & & $\chi^{2}=0.41 ; \mathrm{p}=0.52$ \\
\hline male & 74 & 2,298 & \\
\hline female & 28 & 1,004 & \\
\hline Education (years of schooling) & & & $\chi^{2}=5.84 ; \mathrm{DF}=4 ; \mathrm{p}=0.21$ \\
\hline Illiterate & 1 & 63 & \\
\hline 1 to 3 & 15 & 300 & \\
\hline 4 to 7 & 24 & 756 & \\
\hline 8 to 11 & 23 & 935 & \\
\hline$\geq 12$ & 13 & 536 & \\
\hline Exposure category & & & $\chi^{2}=5.66 ; \mathrm{DF}=2 ; \mathrm{p}=0.06$ \\
\hline MSM & 25 & 1,077 & \\
\hline Heterosexual & 29 & 1,517 & \\
\hline IDU & 15 & 370 & \\
\hline Residence according to income & & & $\chi^{2}=9.64 ; \mathrm{DF}=2 ; \mathrm{p}=0.008$ \\
\hline $\mathrm{R} \$ 1,000.00$ or more & 19 & 637 & \\
\hline $\mathrm{R} \$ 500.00$ to $\mathrm{R} \$ 999.00$ & 21 & 1,113 & \\
\hline Up to $\mathrm{R} \$ 499.00$ & 58 & 1,413 & \\
\hline Age group (years) & & & $\chi^{2}=5.41 ; \mathrm{DF}=4 ; \mathrm{p}=0.24$ \\
\hline$<20$ & 1 & 8 & \\
\hline 20 a 29 & 8 & 289 & \\
\hline 30 a 39 & 30 & 1,181 & \\
\hline 40 a 49 & 39 & 1,251 & \\
\hline$\geq 50$ & 24 & 573 & \\
\hline
\end{tabular}

Source of data: Information System of Notifiable Diseases; $\chi^{2}$ : chi-square; DF: Degrees of freedom; MSM: men who have sex with men; IDU: injecting drug users.

TABLE 3 - Factors that were associated with risk of death from aids after multivariate logistic regression analysis, Brasília, Brazil, 2007.

\begin{tabular}{|c|c|c|c|c|}
\hline Factor & Coefficient & P value & OR & $95 \% \mathrm{CI}$ \\
\hline Intravenous drug use & 0.76 & 0.01 & 2.13 & $1.16-3.91$ \\
\hline Being over 50 years of age & 0.60 & 0.04 & 1.82 & $1.02-3.24$ \\
\hline
\end{tabular}

Source of data: Information System of Notifiable Diseases; OR: odds ratio; CI: confidence interval. 


\section{DIscussion}

\section{Injecting drug user AIDS patients and risk of death}

Authors such as Helena, et al (2009), in Blumenau, Brazil, and Ewing et al (2008), in the United Kingdom, had already observed a lower survival rate among injecting drug users with AIDS ${ }^{4,5}$. Alcohol and other drug abuse make adherence to treatment difficult ${ }^{13}$ and often also leads to late diagnosis because of the harmful effects of these substances on the behavior of those who use them. These facts may be related to the higher chance of death among injecting drug users, which, in 2007, in the Federal District, according to the OR on multivariate analysis, was estimated in this study to be $113 \%$ higher than that of patients who belonged to other exposure categories.

\section{Age of AIDS patients and risk of death}

The association of age over 50 years with a higher risk of death from AIDS may be related to comorbidities, such as chronic degenerative diseases, which are more common after the age of 50, and also to the late diagnosis of AIDS.

Delayed access to health services, characterized by impairment of the immune and clinical condition, occurs more often in men and older people. People over 60 years, for example, are 6.95 times more likely to have a delayed diagnosis [symptomatic and with a T CD4 (cluster of differentiation) lymphocyte count below 200 cells $/ \mathrm{mm}^{3}$ ] when compared with people 15 to 19 years of age ${ }^{14}$.

Ewing et al. found that people who become infected with HIV at older ages had lower survival rates ${ }^{4}$.

In a review of the literature, Bonolo et al. found 17 articles that analyzed statistically the association of age with non-adherence to treatment. In eight articles they found a statistically significant association between younger age groups and non-adherence to treatment ${ }^{15}$. In Brazil (the State of Rio Grande do Norte), Brito et al. also found a statistically significant association between the age group 20-34 years and the interruption of treatment ${ }^{16}$. It seems, therefore, that the larger number of deaths in the age group above 50 years, possibly, is not related to lower adherence to treatment at an advanced age compared with younger ones.

\section{Socioeconomic characteristics of patients with AIDS and risk of death}

Where socioeconomic aspects are concerned, Carvalho et al. showed, in a study conducted in the Federal District of Brazil in 2006, that low income and low education were associated with nonadherence to treatment of AIDS ${ }^{17}$. With the results of the present study, we would add that residence in regions with low per capita income is associated with increased risk of death for people with AIDS.

There was no association between risk of death and schooling in this study. The existence of an association between education level and adherence to antiretroviral therapy in AIDS patients was investigated in 13 studies included in a systematic literature review conducted by Falagas et al. Of these studies, only four showed a statistically significant association between low levels of education and non-adherence. In one study conducted in Botswana by Weiser et al., a negative association between this variable and adherence was observed, i.e., lower education was associated with greater adherence. No hypotheses were presented, however, that could explain this finding ${ }^{18}$. So far, the information available in literature does not allow us to affirm if there is an association between the level of education and treatment adherence.

It is possible that the variables education and residence according to income are related. The District Sample Survey of Households found that the distribution of per capita income of the regions of the Federal District is directly proportional to the level of education of their habitants ${ }^{19}$.

\section{Difficulty of access to health services among low-income AIDS patients}

The greater risk of death observed in this study among those living in places with low income may be related to the greater difficulty in accessing health services.

Having access to health services was a facilitating factor for the adherence to antiretroviral therapy ${ }^{15}$. In the Federal District, the public health units that are a reference to AIDS treatment are distributed as follows: five units at the sites considered in this study as having average to high per capita income ( $\mathrm{R} \$ 500.00$ or more) and three in low-income locations (up to R $\$ 499.00$ ). The income information of the locations of the Federal District was taken from the District Sample Survey of Households ${ }^{19}$.

Of the residents in places of average and high per capita income (964,809 inhabitants), 58.2\% (561,507 inhabitants) have a unit for treatment of AIDS in their region and 41.8\% (403,302 inhabitants) do not. Among the residents of low-income areas $(1,469,224$ inhabitants), on the other hand, this distribution is different: $46.3 \%$ $(679,835$ inhabitants) have a unit of reference in their area and $53.7 \%$ (789,389 inhabitants) do not.

Therefore, when considering the implementation of new public health units of reference for AIDS treatment, the State Health Department of the Federal District (SES-DF) must also consider, among the factors relevant to determining the location of the unit, the population's income per capita, prioritizing low-income areas. Besides the economic difficulty of transportation due to the low income of the population and the large number of persons residing without reference units in their region, these regions faced $65 \%$ higher odds of death among AIDS patients compared with residents of other regions in 2007, according to the results of this study.

\section{Gender and risk of death from AIDS}

Women in general are more diligent than men in visiting health service ${ }^{20}$, but contrary to what one might think, the factor male was not associated with increased risk of death.

\section{The influence of late diagnosis in AIDS deaths included in the study}

Death is a time-dependent event, i.e., patients with longer disease duration are more likely to die. Knowing the date of onset of each patient and pairing the groups following this criterion would eliminate the possible bias that could result from allocating to the group of cases (deaths) those with long disease duration and to the controls (alive) those with low duration. Information about the date of onset, however, is not available, and the one information that could come closest to this is the date of diagnosis. Nevertheless, one can observe that the average period between the date of the registered diagnosis and death in the group of cases (deaths) was lower $(\mathrm{p}<0.001)$ than the average period between the date of the registered diagnosis and the last day of the year 2007 in the control group 
(alive). Being diagnosed for a long time, therefore, appears not to have contributed to the death, but rather the opposite. These findings suggest that there was, among the deaths, a late registration of the diagnosis in the SINAN system, which can effectively occur due to the late realization of the diagnosis or because of the absence of an epidemiological investigation of those cases where health authorities became aware of the occurrence only because of the death certificate. This happens because in the latter case, the date of death itself is entered in the SINAN system as the date of diagnosis.

\section{Other limitations of the study}

One of the limitations of this study was the large number of records where the fields on the variables under study were not filled out or where they were filled out ignoring the code of the relevant information. In the group of cases, 26 (25.5\%) records had no information regarding race, and in the control group, 1,800 (54.5\%) records had no such information. For this reason this variable was not analyzed statistically. This proportion was also high for the variables education (25.5\% among cases and $21.6 \%$ among controls) and exposure category (32.4\% among cases and $9.8 \%$ among controls). Due to possible measurement bias, this weakens the associations found for these variables. With respect to the variables place of residence according to income and age, the proportion of records with missing or incomplete information was lower. For the variable gender, all records had the respective field completed.

Some factors had a small number of records in the studied sample, which made their analysis impossible. Included in this situation are the factors no education and age less than 20 years as well as the exposure categories hemophiliacs, blood transfusion, and vertical transmission.

\section{Conclusion and recommendation}

We identified three factors associated with death from AIDS in the Federal District in 2007: intravenous drug use, being over 50 years of age, and residing in a region where the population has a low income. Public policies that aim to reduce the mortality rate from AIDS, especially those that promote adherence to treatment and early diagnosis of HIV infection, should consider the profile of the patients most at risk of death, characterized by the factors mentioned.

\section{CONFLICT OF INTEREST}

The authors declare that there is no conflict of interest.

\section{REFERENCES}

1. Joint United Nations Programme on HIV/AIDS (UNAIDS). AIDS Epidemic Update [Internet]. Genebra, Switerlzand: World Health Organization; 2009 December. [cited 2010 Jul 15]. Available from http://data.unaids.org/pub/ Report/2009/JC1700_Epi_Update_2009_en.pdf/.

2. Ministério da Saúde. Recomendações para terapia antirretroviral em adultos infectados pelo HIV 2008 [Internet]. Brasília: Ministério da Saúde; 2008 [cited 2009 December 9]. Available from: http://www.aids.gov.br/ data/documents/storedDocuments/\%7BB8EF5DAF-3AE-4891-AD361903553A3174\%7D/\%7B762E0EBF-A859-4779-8A92-704EB1F3B290\%7D/ consensoAdulto005c_2008montado.pdf/.
3. Greco BD, Simão M. Brazilian policy of universal access to AIDS treatment: sustainability challenges and perspectives. AIDS 2007; 21 (supl IV):37-45.

4. Ewings FM, Bhaskaran K, Mclean K, Hawkins D, Fisher M, Fidler S, et al. UK Register of HIV Seroconverters. Survival following HIV infection of a cohort followed up from seroconversion in the UK. AIDS 2008; 22:89-95.

5. Helena ETS, Mafra MLS, Simes M. Fatores associados à sobrevida de pessoas vivendo com aids no Município de Blumenau, Estado de Santa Catarina, Brasil, 1997-2004. Epidemiol Serv Saude 2009; 18:45-53.

6. Farias N, Cardoso MR. A Mortalidade por aids e indicadores sociais no Município de São Paulo, 1994 a 2002. Rev Saude Publica 2005; 39:198-205.

7. Oliveira MTC. O Diagnóstico tardio e óbito por aids de pacientes internados em 2005 em um hospital de referência para doenças infecciosas em Belo Horizonte, Minas Gerais. [Doctors Thesis]. [Belo Horizonte]: Programa de Pós-Graduação em Ciências da Saúde. Universidade Federal de Minas Gerais; 2007. 75p.

8. Ministério da Saúde. Boletim epidemiológico AIDS e DST. Ano VI n. ${ }^{\circ}$ 1. Brasília: Ministério da Saúde; 2009.

9. Secretaria de Estado de Saúde do Distrito Federal. Boletim Epidemiológico de DST/AIDS do Distrito Federal no 02/2008. Brasília: Secretaria de Estado de Saúde; 2008

10. Secretaria de Estado de Saúde do Distrito Federal (SES-DF). Dados e Indicadores Epidemiológicos do Distrito Federal [Internet]. Brasília: SES-DF; 2009 [cited 2009 November 20]. Available from: http://www.saude.df.gov.br/.

11. Gomes RR, Machado CJ, Acurcio FA, Guimarães MDC. Utilização dos Registros de Dispensação da Farmácia como Indicador da Não-Adesão à Terapia Anti-Retroviral em Indivíduos Infectados pelo HIV. Cad Saude Publica 2009; 25:495-506.

12. Ministério da Saúde. Secretaria de Vigilância em Saúde. Programa Nacional de DST e AIDS. Critérios de definição de casos de AIDS em adultos e crianças. Série Manuais n 60. Brasília: Ministério da Saúde; 2004.

13. Ministério da Saúde. Diretrizes para o fortalecimento das ações de adesão ao tratamento para pessoas que vivem com HIV e AIDS [Internet]. Brasília; 2007 [cited 2008 August 11]. Available from: http://www.aids. gov.br/data/documents/storedDocuments/\%7BB8EF5DAF-23AE4891-AD36-1903553A3174\%7D /\%7B570B40AB-A209-4465-AA2770E4AF08CDA1\%7D/Diretrizes\%20adesao\%202007.pdf.

14. Joint United Nations Programme on HIV/AIDS (UNAIDS). UNGASS: Brazilian Response HIV/AIDS 2005-2007 - Country Progress Report [Internet]. Brasília: Ministério da Saúde; 2008 [cited 2010 January 5]. Available from: http:// www2.aids.gov.br/data/documents/storedDocuments/\%7BB8EF5DAF23AE-4891-AD36-1903553A3174\%7D/\%7BDAF508F2-A01D-4DA3-B74B14EE1AE4B98D\%7D/ungass\%202008\%20ingles\%2007-final.pdf/.

15. Bonolo PF, Gomes RR, Guimaraes MD. Adesão à terapia antirretroviral (HIV/ AIDS): fatores associados e medidas da adesão. Epidemiol Serv Saude 2007; 16:267-278.

16. Brito AM, Szwarcwald CL, Castilho EA. Fatores associados à interrupção de tratamento anti-retroviral em adultos com aids: Rio Grande do Norte, Brasil, 1999 - 2002. Rev Assoc Med Bras 2006; 52:2

17. Carvalho CV, Merchan-Hamann E, Matsushita R. Determinantes da adesão ao tratamento antirretroviral em Brasília, DF: um estudo de caso-controle. Rev Soc Bras Med Trop 2007; 40:555-565.

18. Falagas ME, Zarkadoulia EA, Pliatsika PA, Panos G. Socioeconomic status (SES) as a determinant of adherence to treatment in HIV infected patients: a systematic review of literature. Retrovirology 2008; 5:13.

19. Governo do Distrito Federal. Companhia de Planejamento do Distrito Federal (CODEPLAN). Pesquisa Distrital por Amostra de Domicílios (Pdad). Brasília: Codeplan; 2004.

20. Travassos C, Viacava F, Pinheiro R, Brito A. Utilização dos serviços de saúde no Brasil: gênero, características familiares e condição social. Rev Panam Salud Publica 2002; 11:365-373. 